\title{
PEDIATRIC INFLAMMATORY MULTISYSTEM SYNDROME TEMPORALLY ASSOCIATED WITH SARS-COV-2 INFECTION
}

\author{
Lobzin YuV ${ }^{1,2,4}$, Uskov AN ${ }^{1}$, Skripchenko NV ${ }^{1,3}$, Vilnits $A A^{1,3}$, Bekhtereva MK $^{1,3}$, Babachenko IV ${ }^{1,3}$ \\ ${ }_{1}^{1}$ Pediatric Research and Clinical Center for Infectious Diseases of FMBA, Saint Petersburg, Russia \\ ${ }^{2}$ Mechnikov North-West State Medical University, Saint Petersburg, Russia \\ ${ }^{3}$ Saint Petersburg State Pediatric Medical University, Saint Petersburg, Russia \\ ${ }^{4}$ Kirov Military Medical Academy, Saint Petersburg, Russia
}

\begin{abstract}
Despite the low incidence, low mortality and relatively mild symptoms of COVID-19 in children, there has been a rise in pediatric patients who develop a condition resembling Kawasaki disease after COVID-19 or contact with individuals infected with SARS-CoV-2. This condition is known as the pediatric inflammatory multisystem syndrome temporally associated with SARS-CoV-2 infection (PIMS-TS). This review introduces the reader to the hypotheses of PIMS-TS pathogenesis, provides information about its diagnosis and treatment, presents clinical and laboratory data and describes treatments strategies used in children and adolescents hospitalized to the intensive care unit of the Pediatric Research and Clinical Center for Infectious Diseases. Besides, the review outlines the main diagnostic and prognostic challenges of PIMS-TS.
\end{abstract}

Keywords: multisystem inflammatory syndrome, coronavirus infection, COVID-19, SARS-CoV-2, children

Author contribution: Lobzin YuV, Uskov AN, Skripchenko NV — study concept and design; Vilnits AA, Bekhtereva MK, Babachenko IV — data acquisition and processing, statistical analysis, manuscript preparation; Skripchenko NV — editing.

Correspondence should be addressed: Alla A. Vilnits

Professora Popova, 9, Saint Petersburg, 197022; vilnitz@mail.ru

Received: 07.06.2021 Accepted: 21.06.2021 Published online: 26.06.2021

DOI: $10.47183 /$ mes.2021.017

\section{COVID-19-АССОЦИИРОВАННЫЙ ПЕДИАТРИЧЕСКИЙ МУЛЬТИСИСТЕМНЫЙ ВОСПАЛИТЕЛЬНЫЙ СИНДРОМ}

\author{
Ю. В. Лобзин ${ }^{1,2,4}$, А. Н. Усков ${ }^{1}$, Н. В. Скрипченко ${ }^{1,3}$, А. А. Вильниц ${ }^{1,3}$, М. К. Бехтерева ${ }^{1,3}$, И. В. Бабаченко \\ 1 Детский научно-клинический центр инфекционных болезней Федерального медико-биологического агентства, Санкт-Петербург, Россия \\ ${ }^{2}$ Северо-Западный государственный медицинский университет имени И. И. Мечникова, Санкт-Петербург, Россия \\ ${ }^{3}$ Санкт-Петербургский государственный педиатрический медицинский университет, Санкт-Петербург, Россия \\ ${ }^{4}$ Военно-медицинская академия имени С. М. Кирова, Санкт-Петербург, Россия
}

\begin{abstract}
Несмотря на невысокую заболеваемость и летальность, относительно легкое течение COVID-19 в педиатрической популяции, в последнее время у детей после перенесенной коронавирусной инфекции или контакта с инфицированным выросло число случаев развития состояния, по клинической картине схожего с болезнью Кавасаки, которое получило название педиатрический мультисистемный воспалительный синдром, ассоциированный с COVID-19 (ПМВC). В обзоре представлены современные взгляды на возможный патогенез данного состояния, диагностику и лечение, а также данные по клинико-инструментальной картине и тактике ведения ПМВС у детей и подростков, госпитализированных в отделение интенсивной терапии Детского научно-клинического центра инфекционных болезней. Изложены основные проблемы своевременной диагностики и прогнозирования исходов ПМВС у детей.
\end{abstract}

Ключевые слова: воспалительный мультисистемный синдром, коронавирусная инфекция, COVID-19, SARS-CoV-2, дети

Вклад авторов: Ю. В. Лобзин, А. Н. Усков, Н. В. Скрипченко - концепция и дизайн исследования; А. А. Вильниц, М. К. Бехтерева, И. В. Бабаченко сбор и обработка материала, статистическая обработка, написание текста; Н. В. Скрипченко - редактирование.

$\triangle$ Для корреспонденции: Алла Ароновна Вильниц

ул. профессора Попова, д. 9, г. Санкт-Петербург, 197022 ; vilnitz@mail.ru

Статья получена: 07.06.2021 Статья принята к печати: 21.06.2021 Опубликована онлайн: 26.06.2021

DOI: $10.47183 /$ mes.2021.017

The pandemic of the novel coronavirus infection (COVID-19) is still raging; so far, over 130 million confirmed cases and 2.8 million death from COVID-19 have been reported [1]. According to different sources, children make up approximately $2-5 \%$ of the affected patients [2-4]. Across Russia, the prevalence of COVID-19 in children is 1-8.6\% [5], and in most cases the disease is asymptomatic or mild. According to the US Centers for Disease Control and Prevention (CDC), pediatric mortality from COVID-19 is less than $0.1 \%$, while the hospitalization rate is about $2.5 \%$. Of all children and adolescents hospitalized for COVID-19, only 0.8\% required intensive care [6]. Severe comorbidities were the primary cause of admission to intensive care units.

However, in April 2020 reports started to emerge in US, UK $[7,8]$ and then other countries about the growing number of children and adolescents hospitalized to intensive care units with symptoms resembling Kawasaki disease, signs of damage to multiple organs, the clinical picture of toxic or septic shock, and myocarditis with subsequent cardiogenic shock. In all those cases, the patients had a history of contact with individuals infected with SARS-CoV-2 2-6 weeks prior to the onset of symptoms or had SARS-CoV-2-specific antibodies. Notably, the symptoms of acute COVID-19 in most of those children admitted to intensive care units were very mild and their nasopharyngeal swabs collected at the time of admission for PCR tests were negative for SARS-CoV-2. In Europe, their condition was named the pediatric inflammatory multisystem syndrome temporally associated with SARS-CoV-2 infection (PIMS-TS). In the USA, the condition is referred to as multisystem inflammatory syndrome in children (MIS-C). 


\section{Hypothetical mechanisms of PIMS-TS}

The pathogenesis of PIMS-TS is a subject of ongoing debate. There is a hypothesis that the key implicated factor is delayed interferon production at the onset of SARS-CoV-2 infection, which results in severe disease and significant damage to the lungs in older patients at week 2 after infection. In children, PIMSTS appears to develop after the virus is no longer detected on naso- and oropharyngeal mucosa by laboratory tests $[9,10]$. According to another hypothesis, the underlying mechanism of PIMS-TS is similar to that of Dengue fever and relies on the antibody-dependent enhancement of viral replication via phagocytosis and death of immune cells, which, in turn, causes septic shock and multiorgan failure [11]. The literature describes a clinical case of a child with PIMS-TS who died of heart failure; the post-mortem pathomorphological examination detected the presence of the virus in the patient's cardiac muscle tissue, suggesting that virus-mediated tissue injury may have been a potential contributor to PIMS-TS [12]. Macrophage activation syndrome has a very similar pathogenesis; it is observed in children with systemic juvenile idiopathic arthritis and COVID19-related hemophagocytic lymphohistiocytosis [13-15]. Similar to Kawasaki disease, autoantibodies are suspected to play a role in the pathogenesis of PIMS-TS. It is reported that autoantibody levels in infected children with PIMS-TS are higher than in healthy children, children with acute COVID-19 and those with Kawasaki disease. Autoantibodies participating in lymphocyte activation, intracellular signaling and cardiogenesis are superexpressed in PIMS-TS patients. Some autoantibodies to various types of casein kinase are only seen it patients with PIMS-TS. The involvement of multiple organs and tissues in PIMS-TS might be explained by the ubiquity of potential targets for such autoantibodies [16]. According to recent reports, patients with PIMS-TS have elevated levels of IL18 and IL6, increased lymphocytic and myeloid chemotaxis and mucosal immune dysregulation [17]. Hyperinflammation in patients with PIMS-TS differs from that associated with Kawasaki disease, in which IL17A plays the key role; it is also different from acute COVID-19 in children and cytokine storm in adults [16].

\section{Clinical and laboratory criteria for PIMS-TS}

According to systematic reviews [18-22], clinical manifestations of PIMS-TS include a persistent (at least 5-day-long) fever observed in $97-100 \%$ of cases, skin symptoms (rashes in 36$81 \%$ of cases), mucosal involvement (conjunctivitis and cheilitis in $30-94 \%$ of cases), edema in feet and hands (16-68\%), and mild lymphadenopathy (10-60\%). Gastrointestinal symptoms are reported in $84-87 \%$ of cases, setting in at the earliest stages of the disease, and manifest as pain in the stomach, vomiting and diarrhea. Respiratory systems (cough and rhinorrhea) are less common (12-34\%). Cardiovascular involvement is seen in $25 \%$ of patients with PIMS-TS; according to ultrasonography data, some patients develop coronary artery damage without myocarditis and acute coronary syndrome, which distinguishes PIMS-TS from Kawasaki disease: in Kawasaki disease, the risk of arterial damage is inversely proportional to age and is observed in infants during the first year of life, whereas PIMSTS develops in older children and adolescents: according to different literature sources, the median age for this disease is $8-9$ years $[19,20,23,24]$. In some cases, damage to the cardiovascular system manifests as acute myocardial injury accompanied by cardiogenic and vasodilatory shock that requires vasopressor and inotropic therapy, and by elevated cardiac myocytolysis markers [21, 22, 25]. Importantly, 26-56\% of children with PIMS-TS have neurological symptoms, like headache, mental confusion or meningeal symptoms [19].

Laboratory tests show that patients with PIMS-TS have significantly elevated proinflammatory markers (C-reactive protein, procalcitonin, ferritin, ESR, IL6, fibrinogen). Markers of myocardial injury (brain natriuretic propeptide, N-terminal pro-brain natriuretic peptide, troponin) can be elevated in such patients, too. Most patients with PIMS-TS have heightened D-dimer, neutrophilia, lymphocytopenia and low albumin. Thrombocytopenia is another PIMS-TS feature distinguishing it from classic Kawasaki disease. ECG may be suggestive of repolarization abnormalities, focal ischemic changes, conduction anomalies and arrhythmias. In 60\% of PIMS-TS cases, echocardiography reveals signs of myocarditis, including reduced left ventricular ejection fraction $(\leq 50 \%)$ in half of the cases, pericardial effusion in 34\% of cases and coronary artery dilatation in $23 \%$ of cases [19]. Abdominal ultrasound scans may be suggestive of hepatosplenomegaly, lymphadenopathy, ascites, colitis or ileitis $[6,26]$. Chest X-ray and CT features may include ground glass opacities in the lungs, changes to the interstitium, possibly associated with insufficient blood supply, acute respiratory distress syndrome and coagulation disorders.

The absence of confirmed involvement of a causative agent other than SARS-CoV-2 in the symptoms listed above is a crucial criterion for establishing the diagnosis of PIMS-TS. The differential diagnosis should include sepsis, toxic shock caused by streptococci or staphylococci, and enterovirus-associated myocardial injury, Kawasaki disease, macrophage activation syndrome, hemophagocytic lymphohistiocytosis, and the onset of a systemic connective tissue disease [27].

$\mathrm{CDC}$ and $\mathrm{WHO}$ have proposed diagnostic approaches to PIMS-TS accounting for the results of clinical and laboratory tests and the past medical history of the patient. The most elaborate diagnostic and management guidelines for PIMS-TS have been put forward by the consensus of UK experts (Table).

The diagnosis of PIMS-TS is hampered at the prehospital stage. The onset of PIMS-TS shares similarities with early symptoms of other infectious diseases. As a result, patients with PIMS-TS are often referred to the departments of infectious diseases for intestinal, neurological or other respiratory infections. Considering the high risk of life-threatening conditions in patients with PIMS-TS, it is crucial to timely identify children with PIMS-TS in order to initiate immediate treatment and minimize poor outcomes.

\section{PIMS-TS in Saint Petersburg}

At present, the prevalence of PIMS-TS in Russia in general and Saint Petersburg in particular is unknown because the disease is often classified to ICD codes used for other conditions. However, it is still possible to conduct a preliminary analysis of admissions for COVID-19-associated PIMS-TS to intensive care units of Saint Petersburg hospitals for infectious diseases during the epidemic.

The first pediatric admissions with clinical and laboratory signs of PIMS-TS were reported in April and May, 2020. The first patients with PIMS-TS admitted to the City Clinical Hospital for Children № 5 (the main inpatient care facility that admits pediatric patients with COVID-19) were reported in June 2020, 2 months after the Hospital began to admit adult patients with acute COVID-19. In Saint-Petersburg, the surge in PIMS-TS cases occurred in the fall of 2020. From November 2020 through January 2021, the City Clinical Hospital for Children № 5 and the Saint Petersburg State Pediatric Medical University 
Table. Diagnostic guidelines for PIMS-TS

\begin{tabular}{|c|c|c|}
\hline \multicolumn{2}{|c|}{ Criteria } & Parameters \\
\hline \multirow{11}{*}{\multicolumn{2}{|c|}{ Clinical }} & Age $<21$ years \\
\hline & & + body temperature above $38^{\circ} \mathrm{C}$ for $\geq 1$ day \\
\hline & & + hospitalization required \\
\hline & & Plus $\geq$ one of the following: \\
\hline & & Low blood pressure or signs of cardiogenic/vasodilatory shock \\
\hline & & $\begin{array}{l}\text { Signs of serious cardiac injury (signs of myocarditis, pericarditis, valvulitis, elevated troponin/natriuretic peptide, } \\
\text { coronary anomalies, etc.) }\end{array}$ \\
\hline & & Or \\
\hline & & Plus $\geq$ two of the following: \\
\hline & & Maculopapular eruption \\
\hline & & Bilateral non-purulent conjunctivitis \\
\hline & & Signs of oral mucosa or limb skin involvement \\
\hline & & + Two or more of the following laboratory parameters: \\
\hline & Standard & $\begin{array}{l}\text { Neutrophilia, lymphopenia, thrombocytopenia, hypoalbumenia, elevated CRP, ESR, fibrinogen, ferritin, D-dimer, IL6, } \\
\text { OR elevated procalcitonin }\end{array}$ \\
\hline 茪 & & One of following SARS-CoV-2 tests: \\
\hline$\frac{0}{\pi}$ & Virologic/ & Positive PCR test at the time of presentation or within 4 weeks prior to presentation \\
\hline & & Presence of IgM or IgG antibodies \\
\hline & & + One or more factors within 6 weeks prior to onset of symptoms: \\
\hline & & Close contact with infected person \\
\hline Epid & ological & $\begin{array}{l}\text { Close contact with patient with COVID-19 symptoms who had a history of contact with another individual with COVID-19 } \\
\text { confirmed by laboratory tests }\end{array}$ \\
\hline & & Travelling to or living in areas with COVID-19 spread \\
\hline of $\mathrm{C}$ & $\begin{array}{l}\text { ition } \\
\text { al case }\end{array}$ & $\begin{array}{l}\text { Confirmed (from clinical, laboratory and virologic/serologic tests) } \\
\text { Possible (from clinical, standard laboratory, and epidemiological data) }\end{array}$ \\
\hline
\end{tabular}

admitted 25 and 17 children, respectively, meeting the criteria for PIMS-TS [28].

During the preCOVID era, the incidence of Kawasaki disease in Saint Petersburg was less than 1.6 per 100,000 children under 18 years; in November and December, it increased to 5.2 per 100,000 children, i.e. it could be estimated as 20 cases per 100,000 pediatric population over 12 months. From November through January, there was a 10-15-fold increase in PIMS-TS cases; its future dynamics are difficult to predict.

According to the Pediatric Research and Clinical Center for Infectious Diseases, the number of hospitalizations for Kawasaki disease disguised as a gastrointestinal infection did not exceed 3-5 before 2018. But between January 2018 and December, 2020, as many as 30 children were hospitalized (10-12 children per year) with Kawasaki symptoms. In most cases, the patients were boys under 5 years who met the 2006 EULAR/PreS consensus criteria for vasculitides [29, 30].

Saint-Petersburg reported the first patients with PIMS-TS in April and May 2020. A few unusual Kawasaki cases were detected retrospectively in December 2019. This does not rule out the possibility of the virus having sneaked into the population earlier. By August 2020, the PIMS-TS wave had almost subsided; new cases began to emerge in October 2020, and keep coming in now.

The Pediatric Research and Clinical Center for Infectious Diseases admitted the first patient with PIMS-TS in October 2020; over the course of 4 weeks starting from late December 2020, 14 more children with PIMS-TS were hospitalized. In contrast to Kawasaki disease, all admitted patients were older than 4 years, of them $53 \%$ were girls $(n=8)$. The mean age of the children was $11.25 \pm 3.28$ years for boys and $8.75 \pm 3.99$ years for girls. All the children were hospitalized for persistent fever lasting for over 3 days (3.77 \pm 2.08 days). Of them,
$20 \%$ were hospitalized on day 1-2 after onset, the rest were admitted on day $4.46 \pm 1.66$ after onset. The main referral diagnosis was acute respiratory infection $(53 \% ; n=8)$ or acute gastroenteritis (33.3\%; $n=5)$. On admission, $67 \%$ of children had exanthema and $30 \%$ had diarrhea. Markers of pronounced systemic inflammation were detected by laboratory tests in all patients at the time of admission: C-reactive protein was elevated (>150 mg/L) in $100 \%$ cases; 8 out of 10 children who took a procalcitonin test had high procalcitonin levels. In all cases, signs of cardiac injury were detected. In one case, the patient had a history of the novel coronavirus infection (2 months before admission to the Center); 3 children (20\%) had a history of contact with a potentially infected person; 14 children (93.3\%) had IgG against SARS-CoV-2. PCR tests showed that all collected naso- and oropharyngeal swabs were negative for SARS-CoV-2.

In order to understand the etiology of the disease, a few laboratory tests were conducted. In $66.7 \%(n=10)$ of cases, the pathogen was identified (mostly enteroviruses and Yersiniaceae). Two or more pathogens that could cause the symptoms were implicated in $20 \%$ of cases. But the confirmed presence of the pathogen could not explain the severity of inflammation and the frequency of organ involvement, including the heart, in initially healthy children.

\section{CONCLUSION}

Currently, PIMS-TS is a diagnosis by exclusion. However, it is not fully clear whether PIMS-TS should be excluded in the presence of other etiologic factors contributing to the disease. There is no clear understanding whether PIMS-TS is an independent disease that develops in children with a history of COVID-19 or a pathologic immune response to other 
etiologic agents in patients recovering from mild/asymptomatic COVID-19. More data, including laboratory testing results, are needed about the course of different infections in children and adolescents with a past history of COVID-19.

We cannot predict whether a child is at risk for PIMS-TS after contracting a co-infection, considering that COVID-19 is asymptomatic in most children and teenagers.

A child at risk for PIMS-TS may present at any specialist, including a pediatrician or a specialist in infectious diseases. The doctor will be responsible for making a decision on hospitalization or immediate initiation of therapy. Although all clinicians are familiar with the clinical guidelines for the management of patients with COVID-19, many of them do not have sufficient knowledge about PIMS-TS and are not aware of the approaches to its treatment. In contrast to Kawasaki disease, there is no evidence that intravenous immunoglobulins have any advantages over other therapies or are indicated for PIMS-TS. There are not clear indications and regimens for anticytokine therapy in children with PIMS-TS. Treatment strategies for such patients are borrowed from clinical rheumatology and hematology, which treat similar conditions, including Kawasaki disease, macrophage activation syndrome and hemophagocytic lymphohistiocytosis.

So far, there are no clear, practical recommendations for identifying patients with suspected or likely PIMS-TS that would help to determine the treatment strategy at different stages of the disease.

PIMS-TS is a multidisciplinary problem. Due to multiorgan involvement, the team of specialists delivering medical care to such patients should include infectious disease specialists, critical care physicians, cardiologists, rheumatologists, radiographers and specialists in functional diagnostics. Patients with PIMS-TS require ICU and cardiovascular monitoring equipment and well-equipped laboratories.

There is no consensus protocol for managing children with PIMS-TS. Russian and foreign guidelines recommend antibiotics, intravenous immunoglobulins, aspirin, glucocorticoids, recombinant interleukin-1 receptor antagonist (anakinra), IL6 inhibitor (tocilizumab), monoclonal antibodies against TNF $\alpha$ (infliximab) [22, 31]. Criteria for assessing indications for different anti-PIMS-TS regimens are yet to be developed.

We do not know long-term sequalae of PIMS-TS. As is the case with Kawasaki disease, there is a possibility that PIMS-TS may cause severe cardiovascular complications not only in the acute stage of the disease but also in the long run. After recovering from Kawasaki disease, patients are followed up by their cardiologists. For PIMS-TS, the follow-up strategy has not been proposed yet. Regardless of the clinical type of PIMSTS, children with a history of this disease must be followed up by their pediatrician. It is important to monitor their hemostatic parameters and perform electro- and echocardiography on a regular basis; such patients should be referred to a cardiologist, neurologist or other specialists should the need arise or should there be signs of damage to other organs.

In 2020, the world faced the first global pandemic of the novel coronavirus disease caused by SARS-COV2 and PIMS-TS. PIMS-TS is a multidisciplinary problem that cannot be solved in the absence of multicenter studies. A task force has been created in Saint Petersburg to study various aspects of PIMS-TS, collect epidemiologic data, information on the clinical course and features of the disease, develop optimal diagnostic strategies and therapeutic regimens for PIMS-TS that could be used in a clinical setting, propose schemes for patient routing in the acute stage of the disease and after discharge home, and provide guidelines for follow-up and rehabilitation.

Although it is very difficult to predict the dynamics of the COPVID-19 epidemic, an association can be established between the rise in PIMS-TS cases and the growing number of COVID-19 patients in the population, which has been reported since the spring of 2020 in USA and some European countries and since the fall of 2020 in Russia. The only realistic method of controlling the spread of COVID-19 is vaccination. Given the severity of PIMS-TS and its unpredictable sequelae, vaccination against COVID-19 for children and adolescents should be considered.

\section{References}

1. WHO Coronavirus (COVID-19) Dashboard. 2021 Apr (cited 2021 Apr 07). Available from: https://covid19.who.int/ .

2. Ludvigsson JF. Systematic review of COVID-19 in children shows milder cases and a better prognosis than adults. Acta Paediatr 2020; 109: 1088-95. PMID: 32202343 DOI: 10.1111/apa.15270.

3. Ding Y, Yan H, Guo W. Clinical Characteristics of Children with COVID-19: A Meta-Analysis. Front Pediatr 2020; 8: 431. PMID: 32719759 DOI: 10.3389/fped.2020.00431.

4. Guo CX, He L, Yin JY, Meng XG, Tan W, Yang GP, et al. Epidemiological and clinical features of pediatric COVID-19. BMC Med 2020; 18: 250. PMID: 32762696 DOI:10.1186/s12916-02001719-2.

5. Uskov AN, Lobzin JuV, Rychkova SV, Babachenko IV, Fedorov W, Uluhanova LU i dr. Techenie novoj koronavirusnoj infekcii u detej: nekotorye aspekty monitoringa zabolevaemosti i analiza letal'nosti. Zhurnal infektologii. 2020; 12 (3): 12-20. DOI: 10.22625/20726732-2020-12-3-12-20. Russian.

6. Leidman E, Duca LM, Omura JD, Proia K, Stephens JW, SauberSchatz EK. COVID-19 Trends Among Persons Aged 0-24 Years United States, March 1-December 12, 2020. MMWR Morb Mortal Wkly Rep. 2021; 70 (3): 88-94. DOI: 10.15585/mmwr. mm7003e1. PMID: 33476314; PMCID: PMC7821770.

7. Jones VG, Mills M, Suarez D, Hogan CA, Yeh D, Segal JB, et al. COVID-19 and Kawasaki Disease: Novel Virus and Novel

Case. Hosp Pediatr. 2020; 10 (6): 537-40. DOI: 10.1542/ hpeds.2020-0123. Epub 2020 Apr 7. PMID: 32265235.

8. Davies P, Evans C, Kanthimathinathan HK, Lillie J, Brierley J, Waters G, et al. Intensive care admissions of children with paediatric inflammatory multisystem syndrome temporally associated with SARS-CoV-2 (PIMS-TS) in the UK: a multicentre observational study. Lancet Child Adolesc Health. 2020; 4 (9): 669-77. DOI: 10.1016/S2352-4642(20)30215-7. PMID: 32653054; PMCID: PMC7347350.

9. Verdoni L, Mazza A, Gervasoni A, Martelli L, Ruggeri M, Ciuffreda M, et al. An outbreak of severe Kawasaki-like disease at the Italian epicentre of the SARS-CoV-2 epidemic: an observational cohort study. Lancet. 2020; 395 (10239): 1771-8. DOI: 10.1016/S01406736(20)31103-X. PMID: 32410760; PMCID: PMC7220177.

10. Rowley AH. Understanding SARS-CoV-2-related multisystem inflammatory syndrome in children. Nat Rev Immunol. 2020; 20 (8): 453-4. DOI: 10.1038/s41577-020-0367-5. PMID: 32546853; PMCID: PMC7296515.

11. Evans C, Davies P. SARS-CoV-2 paediatric inflammatory syndrome. Paediatr Child Health (Oxford). 2021; 31 (3): 110-5. DOI: 10.1016/j.paed.2020.12.003. PMID: 33391390; PMCID: PMC7762804.

12. Dolhnikoff M, Ferreira Ferranti J, de Almeida Monteiro RA, DuarteNeto AN, Soares Gomes-Gouvêa M, Viu Degaspare N, et al. 
SARS-CoV-2 in cardiac tissue of a child with COVID-19-related multisystem inflammatory syndrome. Lancet Child Adolesc Health. 2020; 4 (10): 790-4. DOI: 10.1016/S2352-4642(20)30257-1. PMID: 32828177; PMCID: PMC7440866.

13. Bregel LV, Kostik MM, Fell LZ, Efremova OS, Soboleva MK, Krupskaja TS i dr. Bolezn' Kavasaki i mul'tisistemnyj vospalitel'ny] sindrom pri infekcii COVID-19 u detej. Pediatrija im. G. N. Speranskogo. 2020; 99 (6): 209-19. DOI: 10.24110/0031-403X2020-99-6-209-219. Russian.

14. Ravelli $A$, Minoia F, Davì $S$, Horne A, Bovis F, Pistorio A, et al. 2016 Classification Criteria for Macrophage Activation Syndrome Complicating Systemic Juvenile Idiopathic Arthritis: A European League Against Rheumatism/American College of Rheumatology/ Paediatric Rheumatology International Trials Organisation Collaborative Initiative. Ann Rheum Dis. 2016;75(3):481-9. DOI: 10.1136/annrheumdis-2015-208982. PMID: 26865703.

15. Toubiana J, Poirault C, Corsia A, Bajolle F, Fourgeaud J, Angoulvant $F$, et al. Kawasaki-like multisystem inflammatory syndrome in children during the covid-19 pandemic in Paris, France: prospective observational study. BMJ. 2020; 369: m2094. DOI: 10.1136/bmj.m2094. PMID: 32493739; PMCID: PMC7500538.

16. Consiglio C, Cotugno N, Sardh $F$, et al. The immunology of multisystem inflammatory syndrome in children with COVID-19. 2020; 12; 183 (4): 968-81.e7. DOI: 10.1016/j.cell.2020.09.016. PMID: 32966765; PMCID: PMC7474869.

17. Gruber CN, Patel RS, Trachtman R, Lepow L, Amanat F, Krammer F, et al. Mapping Systemic Inflammation and Antibody Responses in Multisystem Inflammatory Syndrome in Children (MIS-C). Cell. 2020; 183 (4): 982-95.e14. DOI: 10.1016/..cell.2020.09.034. PMID: 32991843; PMCID: PMC7489877.

18. Hoste L, Van Paemel R, Haerynck F. Multisystem inflammatory syndrome in children related to COVID-19: a systematic review. Eur J Pediatr. 2021; 18: 1-16. DOI: 10.1007/s00431-021-039935. PMID: 33599835; PMCID: PMC7890544.

19. Yasuhara J, Watanabe K, Takagi H, Sumitomo N, Kuno T. COVID-19 and multisystem inflammatory syndrome in children: A systematic review and meta-analysis. Pediatr Pulmonol. 2021; 11: 10.1002/ppul.25245. DOI: 10.1002/ppul.25245. PMID: 33428826; PMCID: PMC801339.

20. Tang Y, Li W, Baskota M, Zhou Q, Fu Z, Luo Z, et al. Multisystem inflammatory syndrome in children during the coronavirus disease 2019 (COVID-19) pandemic: a systematic review of published case studies. Transl Pediatr. 2021; 10 (1): 121-35. DOI: 10.21037/ tp-20-188. PMID: 33633944; PMCID: PMC7882293.

21. Daskalakis D. Health Alert\# 13: pediatric multi-system inflammatory syndrome potentially associated with COVID-19 // NYC Health [Internet]. 2020 May [cited 2021 Apr 07]. Available from: https://www1.nyc.gov/assets/doh/downloads/pdf/han/

\section{Литература}

1. WHO Coronavirus (COVID-19) Dashboard. 2021 Apr (cited 2021 Apr 07). Available from: https://covid19.who.int/

2. Ludvigsson JF. Systematic review of COVID-19 in children shows milder cases and a better prognosis than adults. Acta Paediat 2020; 109: 1088-95. PMID: 32202343 DOI: 10.1111/apa.15270.

3. Ding Y, Yan H, Guo W. Clinical Characteristics of Children with COVID-19: A Meta-Analysis. Front Pediatr 2020; 8: 431. PMID: 32719759 DOI: 10.3389/fped.2020.00431.

4. Guo CX, He L, Yin JY, Meng XG, Tan W, Yang GP, et al. Epidemiological and clinical features of pediatric COVID-19. BMC Med 2020; 18: 250. PMID: 32762696 DOI:10.1186/s12916-02001719-2.

5. Усков А. Н., Лобзин Ю. В., Рычкова С. В., Бабаченко И. В., Федоров В. В., Улуханова Л. У. и др. Течение новой коронавирусной инфекции у детей: некоторые аспекть мониторинга заболеваемости и анализа летальности. Журнал инфектологии. 2020; 12 (3): 12-20. DOI: 10.22625/2072-67322020-12-3-12-20.

6. Leidman E, Duca LM, Omura JD, Proia K, Stephens JW, SauberSchatz EK. COVID-19 Trends Among Persons Aged 0-24 Years - alert/2020/covid-19-pediatric-multi-system-inflammatorysyndrome.pdf.

22. Ahmed M, Advani S, Moreira A, Zoretic S, Martinez J, Chorath K, et al. Multisystem inflammatory syndrome in children: A systematic review. EClinicalMedicine. 2020; 26: 100527. DOI: 10.1016/j. eclinm.2020.100527. PMID: 32923992; PMCID: PMC7473262.

23. Jindal AK, Pilania RK, Prithvi A, Guleria S, Singh S. Kawasaki disease: characteristics, diagnosis, and unusual presentations. Expert Rev Clin Immunol. 2019; 15 (10): 1089-104. DOI: 10.1080/1744666X.2019.1659726. PMID: 31456443.

24. Whittaker E, Bamford A, Kenny J, Kaforou M, Jones CE, Shah P, et al. PIMS-TS Study Group and EUCLIDS and PERFORM Consortia. Clinical Characteristics of 58 Children With a Pediatric Inflammatory Multisystem Syndrome Temporally Associated With SARS-CoV-2. JAMA. 2020; 324 (3): 259-69. DOI: 10.1001/ jama.2020.10369. PMID: 32511692; PMCID: PMC7281356.

25. WuL, O'KaneAM, Peng H, BiY, Motriuk-SmithD, RenJ. SARS-CoV-2 and cardiovascular complications: From molecular mechanisms to pharmaceutical management. Biochem Pharmacol. 2020; 178: 114114. DOI: 10.1016/j.bcp.2020.114114. PMID: 32579957; PMCID: PMC7306106.

26. Royal College of Paediatric and Child Health. Guidance: paediatric multisystem inflammatory syndrome temporally associated with COVID-19. 2020 May 01 (cited 2021 Apr 07). Available from: https://www.rcpch.ac.uk/resources/guidance-paediatricmultisystem-inflammatory-syndrome-temporally-associatedcovid-19.

27. Cuomo AM, Zucker HA, Dreslin S. Health advisory: pediatric multi-system inflammatory syndrome potentially associated with coronavirus disease (COVID-19) children //New York State of Opportunity. Department of Health. 2020 May 06 (cited 2021 Jan 24). Available from: https://www.health.ny.gov/ press/releases/2020/docs/2020-05- 06_covid19_pediatric_ inflammatory_syndrome.pdf.

28. Lobzin JuV, Vilnic AA, Kostik MM i dr. Pediatricheskij mul'tisistemnyj vospalitel'nyj sindrom, associirovannyj s novoj koronavirusnoj infekciej: nereshennye problemy. Zhurnal infektologii. 2021; 13 (1): 13-20. https://doi.org/10.22625/2072-6732-2021-13-1-13-20. Russian.

29. Kawasaki T. Kawasaki disease. Proc Jpn Acad Ser B Phys Biol Sci. 2006; 82 (2): 59-71. DOI: 10.2183/pjab.82.59. PMID: 25792773; PMCID: PMC4323050

30. Kawasaki T. Kawasaki disease. Int J Rheum Dis. 2014; 17 (5): 597-600. DOI: 10.1111/1756-185X.12408.

31. Aleksandrovich JuS, Alekseeva El, Bakradze MD i dr. Osobennosti klinicheskih projavlenij i lechenija zabolevanija, vyzvannogo novoj koronavirusnoj infekciej (COVID-19), u detej. Metodicheskie rekomendacii. Versija 2. Pediatricheskaja farmakologija. 2020; 17 (3): 187-212. DOI: 10.15690/pf.v17i3.2123. Russian.

United States, March 1-December 12, 2020. MMWR Morb Mortal Wkly Rep. 2021; 70 (3): 88-94. DOI: 10.15585/mmwr. mm7003e1. PMID: 33476314; PMCID: PMC7821770.

7. Jones VG, Mills M, Suarez D, Hogan CA, Yeh D, Segal JB, et al. COVID-19 and Kawasaki Disease: Novel Virus and Novel Case. Hosp Pediatr. 2020; 10 (6): 537-40. DOI: 10.1542/ hpeds.2020-0123. Epub 2020 Apr 7. PMID: 32265235.

8. Davies P, Evans C, Kanthimathinathan HK, Lillie J, Brierley J, Waters G, et al. Intensive care admissions of children with paediatric inflammatory multisystem syndrome temporally associated with SARS-CoV-2 (PIMS-TS) in the UK: a multicentre observational study. Lancet Child Adolesc Health. 2020; 4 (9): 669-77. DOI: 10.1016/S2352-4642(20)30215-7. PMID: 32653054; PMCID: PMC7347350.

9. Verdoni L, Mazza A, Gervasoni A, Martelli L, Ruggeri M, Ciuffreda M, et al. An outbreak of severe Kawasaki-like disease at the Italian epicentre of the SARS-CoV-2 epidemic: an observational cohort study. Lancet. 2020; 395 (10239): 1771-8. DOI: 10.1016/S01406736(20)31103-X. PMID: 32410760; PMCID: PMC7220177.

10. Rowley $\mathrm{AH}$. Understanding SARS-CoV-2-related multisystem 
inflammatory syndrome in children. Nat Rev Immunol. 2020; 20 (8): 453-4. DOI: 10.1038/s41577-020-0367-5. PMID: 32546853; PMCID: PMC7296515.

11. Evans C, Davies P. SARS-CoV-2 paediatric inflammatory syndrome. Paediatr Child Health (Oxford). 2021; 31 (3): 110-5. DOI: 10.1016/j.paed.2020.12.003. PMID: 33391390; PMCID: PMC7762804.

12. Dolhnikoff M, Ferreira Ferranti J, de Almeida Monteiro RA, DuarteNeto AN, Soares Gomes-Gouvêa M, Viu Degaspare N, et al. SARS-CoV-2 in cardiac tissue of a child with COVID-19-related multisystem inflammatory syndrome. Lancet Child Adolesc Health. 2020; 4 (10): 790-4. DOI: 10.1016/S2352-4642(20)30257-1. PMID: 32828177; PMCID: PMC7440866.

13. Брегель Л. В., Костик М. М., Фелль Л. З., Ефремова О. С., Соболева М. К., Крупская Т. С. и др. Болезнь Кавасаки и мультисистемный воспалительный синдром при инфекции COVID-19 у детей. Педиатрия им. Г. Н. Сперанского. 2020; 99 (6): 209-19. DOI: 10.24110/0031-403X-2020-99-6-209-219.

14. Ravelli $A$, Minoia F, Davì $S$, Horne $A$, Bovis F, Pistorio A, et al. 2016 Classification Criteria for Macrophage Activation Syndrome Complicating Systemic Juvenile Idiopathic Arthritis: A European League Against Rheumatism/American College of Rheumatology/ Paediatric Rheumatology International Trials Organisation Collaborative Initiative. Ann Rheum Dis. 2016;75(3):481-9. DOl: 10.1136/annrheumdis-2015-208982. PMID: 26865703.

15. Toubiana J, Poirault C, Corsia A, Bajolle F, Fourgeaud J, Angoulvant $F$, et al. Kawasaki-like multisystem inflammatory syndrome in children during the covid-19 pandemic in Paris, France: prospective observational study. BMJ. 2020; 369: m2094. DOI: 10.1136/bmj.m2094. PMID: 32493739; PMCID: PMC7500538.

16. Consiglio C, Cotugno N, Sardh F, et al. The immunology of multisystem inflammatory syndrome in children with COVID-19. 2020; 12; 183 (4): 968-81.e7. DOI: 10.1016/..cell.2020.09.016. PMID: 32966765; PMCID: PMC7474869.

17. Gruber CN, Patel RS, Trachtman R, Lepow L, Amanat F, Krammer F, et al. Mapping Systemic Inflammation and Antibody Responses in Multisystem Inflammatory Syndrome in Children (MIS-C). Cell. 2020; 183 (4): 982-95.e14. DOI: 10.1016/j.cell.2020.09.034. PMID: 32991843; PMCID: PMC7489877.

18. Hoste L, Van Paemel R, Haerynck F. Multisystem inflammatory syndrome in children related to COVID-19: a systematic review. Eur J Pediatr. 2021; 18: 1-16. DOI: 10.1007/s00431-021-039935. PMID: 33599835; PMCID: PMC7890544.

19. Yasuhara J, Watanabe $\mathrm{K}$, Takagi $\mathrm{H}$, Sumitomo $\mathrm{N}$, Kuno $\mathrm{T}$. COVID-19 and multisystem inflammatory syndrome in children: A systematic review and meta-analysis. Pediatr Pulmonol. 2021; 11: 10.1002/ppul.25245. DOI: 10.1002/ppul.25245. PMID: 33428826; PMCID: PMC801339.

20. Tang Y, Li W, Baskota M, Zhou Q, Fu Z, Luo Z, et al. Multisystem inflammatory syndrome in children during the coronavirus disease 2019 (COVID-19) pandemic: a systematic review of published case studies. Transl Pediatr. 2021; 10 (1): 121-35. DOI: 10.21037/ tp-20-188. PMID: 33633944; PMCID: PMC7882293.
21. Daskalakis D. Health Alert\# 13: pediatric multi-system inflammatory syndrome potentially associated with COVID-19 // NYC Health [Internet]. 2020 May [cited 2021 Apr 07]. Available from: https://www1.nyc.gov/assets/doh/downloads/pdf/han/ alert/2020/covid-19-pediatric-multi-system-inflammatorysyndrome.pdf.

22. Ahmed M, Advani S, Moreira A, Zoretic S, Martinez J, Chorath K, et al. Multisystem inflammatory syndrome in children: A systematic review. EClinicalMedicine. 2020; 26: 100527. DOI: 10.1016/j. eclinm.2020.100527. PMID: 32923992; PMCID: PMC7473262.

23. Jindal AK, Pilania RK, Prithvi A, Guleria S, Singh S. Kawasaki disease: characteristics, diagnosis, and unusual presentations. Expert Rev Clin Immunol. 2019; 15 (10): 1089-104. DOI: 10.1080/1744666X.2019.1659726. PMID: 31456443.

24. Whittaker E, Bamford A, Kenny J, Kaforou M, Jones CE, Shah P, et al. PIMS-TS Study Group and EUCLIDS and PERFORM Consortia. Clinical Characteristics of 58 Children With a Pediatric Inflammatory Multisystem Syndrome Temporally Associated With SARS-CoV-2. JAMA. 2020; 324 (3): 259-69. DOI: 10.1001/ jama.2020.10369. PMID: 32511692; PMCID: PMC7281356.

25. WuL, O'KaneAM, Peng H, BiY, Motriuk-SmithD, Ren J. SARS-CoV-2 and cardiovascular complications: From molecular mechanisms to pharmaceutical management. Biochem Pharmacol. 2020; 178: 114114. DOI: 10.1016/j.bcp.2020.114114. PMID: 32579957; PMCID: PMC7306106.

26. Royal College of Paediatric and Child Health. Guidance: paediatric multisystem inflammatory syndrome temporally associated with COVID-19. 2020 May 01 (cited 2021 Apr 07). Available from: https://www.rcpch.ac.uk/resources/guidance-paediatricmultisystem-inflammatory-syndrome-temporally-associatedcovid-19.

27. Cuomo AM, Zucker HA, Dreslin S. Health advisory: pediatric multi-system inflammatory syndrome potentially associated with coronavirus disease (COVID-19) children //New York State of Opportunity. Department of Health. 2020 May 06 (cited 2021 Jan 24). Available from: https://www.health.ny.gov/ press/releases/2020/docs/2020-05- 06_covid19_pediatric_ inflammatory_syndrome.pdf.

28. Лобзин Ю. В., Вильниц А. А., Костик М. М. и др. Педиатрический мультисистемный воспалительный синдром, ассоциированный с новой коронавирусной инфекцией: нерешенные проблемы. Журнал инфектологии. 2021; 13 (1): 13-20. https://doi.org/10.22625/2072-6732-2021-13-1-13-20.

29. Kawasaki T. Kawasaki disease. Proc Jpn Acad Ser B Phys Biol Sci. 2006; 82 (2): 59-71. DOI: 10.2183/pjab.82.59. PMID: 25792773; PMCID: PMC4323050.

30. Kawasaki T. Kawasaki disease. Int J Rheum Dis. 2014; 17 (5): 597-600. DOI: 10.1111/1756-185X.12408.

31. Александрович Ю. С., Алексеева Е. И., Бакрадзе М. Д. и др. Особенности клинических проявлений и лечения заболевания, вызванного новой коронавирусной инфекцией (COVID-19), у детей. Методические рекомендации. Версия 2. Педиатрическая фармакология. 2020; 17 (3): 187-212. DOI: 10.15690/pf.v17i3.2123. 